\title{
Identification and characterization of a phospholipase $\mathbf{C}$ activity in resident mouse peritoneal macrophages
}

\author{
Inhibition of the enzyme by phenothiazines
}

\author{
Paul D. WIGHTMAN,* Mary Ellen DAHLGREN, ${ }^{*}$ James C. HALL, $\dagger$ Philip DAVIES* and \\ Robert J. BONNEY* \\ * Department of Immunology, Merck Institute for Therapeutic Research, P. O. Box 2000, Rahway, NJ 07065, \\ and + Department of Zoology, Rutgers University, Newark, NJ 07102, U.S.A.
}

(Received 18 March 1981/Accepted 21 April 1981)

\begin{abstract}
Resident mouse peritoneal macrophages contain a phospholipase $\mathrm{C}$ of high activity that is specific for phosphatidylinositol. The activity has a neutral $\mathrm{pH}$ optimum, is $\mathrm{Ca}^{2+}$-dependent and has a maximum reaction velocity of $525 \mathrm{nmol} / \mathrm{h}$ per $\mathrm{mg}$ of protein. Certain phenothiazines are potent inhibitors of this activity.
\end{abstract}

We have reported that mouse peritoneal macrophages synthesize and release large amounts of prostaglandin $\mathrm{E}_{2}$ and 6-oxoprostaglandin $\mathrm{F}_{1 \alpha}$ when exposed to inflammatory stimuli (Bonney et al., $1978 a, 1979 a, 1980)$. Hsueh et al. (1979) have reported similar findings in rabbit alveolar macrophages responding to zymosan. Hsueh et al. (1979) and Scott et al. (1980) report that macrophages incubated in the presence of radiolabelled arachidonic acid incorporate this label primarily into phosphatidylcholine, phosphatidylethanolamine and phosphatidylinositol. Bonney et al. (1978a) and Hsueh et al. (1979) report that in such prelabelled macrophages the phosphatidylcholine pool is selectively depleted of its arachidonic acid, the precursor of these prostaglandin products. The phospholipase systems of the macrophage involved in these events are not well characterized.

Although it appears that phosphatidylcholine is the major source of arachidonic acid in the macrophage, several investigators have shown that mononuclear phagocytes responding to various stimuli incorporate ${ }^{32} \mathrm{P}$ specifically into phosphatidylinositol. Karnovsky et al. (1966) demonstrated this phenomenon in monocytes undergoing phagocytosis. Graham et al. (1967) reported a similar turnover in phosphatidylinositol in endotoxintreated guinea-pig peritoneal macrophages. Ogmundsdötter \& Weir (1979) reported that $\left[{ }^{3} \mathrm{H}\right]$ myo-inositol incorporation into phosphatidylinositol was stimulated in mouse peritoneal macrophages treated with endotoxin or Corynebacterium parvum. In platelets this enhanced turnover of phosphatidylinositol involves in part the specific hydrolysis of phosphatidylinositol by a phospholipase $\mathrm{C}$ since a product of this turnover is a phosphatidylinositolderived diacylglycerol (Rittenhouse-Simmons,
1979). This diacylglycerol is then phosphorylated to give phosphatidic acid and enters the phosphatidylinositol synthetic pathway de novo. That there exists a coupling of phosphatidylinositol turnover to a phospholipase $\mathrm{A}_{2}$-mediated deacylation of phosphatidylcholine is at this time only speculative. However, Lapetina \& Cuatrecasas (1979) have suggested that such a coupling may be operative in the platelet. They report that phosphatidic acid is among the earliest detectable products in stimulated platelets and, being a potent $\mathrm{Ca}^{2+}$ ionophore (Tyson et al., 1976), can activate $\mathrm{Ca}^{2+}$-dependent phospholipase $A_{2}$. This enzyme, well characterized in the platelet (Apitz-Castro et al., 1979), then deacylates phosphatidylcholine and supplies non-esterified arachidonic acid to the prostaglandin synthase system.

We have recently described two phospholipase $A_{2}$ activities in the macrophage that may be important in the response of this cell to inflammatory stimuli (Wightman et al., 1981). We now describe for the first time a phosphatidylinositol-specific phospholipase $\mathrm{C}$ activity in homogenates of purified resident mouse peritoneal macrophages. We have identified this activity as a phospholipase $\mathrm{C}$ by recovering equimolar amounts of its reaction products, phosphoinositol and diacylglycerol. In addition, we further characterized this enzyme by showing that it is inhibited by phenothiazines, known to inhibit the stimulated release of arachidonic acid from macrophages (Humes et al., 1979) and prostaglandins from platelets (Vanderhoek \& Feinstein, 1979).

\section{Materials}

Male Swiss Webster mice (HLA-SW/ICR SPF) were purchased from Hilltop Lab Animals, Scott- 
dale, PA, U.S.A. M199 medium, components for Higuchi medium (Schroeder et al., 1976) and pig serum were purchased from GIBCO Inc., Grand Island, NY, U.S.A. The pig serum was inactivated by heating at $56^{\circ} \mathrm{C}$ for $30 \mathrm{~min}$. Nunclon tissue culture dishes were from Vangard International, Neptune, NJ, U.S.A. Tissue culture flasks were purchased from Corning Glassworks, Corning, NY, U.S.A. myo-[2(n)- $\left.{ }^{3} \mathrm{H}\right]$ Inositol (sp. radioactivity $12.5 \mathrm{Ci} / \mathrm{mmol}$ ) and $\left[1{ }^{14} \mathrm{C}\right]$ arachidonic acid (sp. radioactivity $51 \mathrm{Ci} / \mathrm{mol}$ ) were purchased from New England Nuclear, Boston, MA, U.S.A. Silica-gel GF t.l.c. plates were from Analtech, Newark, DE, U.S.A. Lipids used as chromatographic standards were obtained from Sigma Chemical Co., St. Louis, MO, U.S.A. All solvents (reagent grade) and inorganic salts were purchased from J. T. Baker Chemical Co., Phillipsburg, NJ, U.S.A. Mouse LM fibroblasts were kindly supplied by Dr. S. Ostrove of these laboratories. Inositol 1-phosphate was supplied by Dr. P. Durette, also of these laboratories.

\section{Methods}

\section{Cell culture}

Macrophages were collected by peritoneal lavage in $5 \mathrm{ml}$ of M199 medium containing $1 \%$ heatinactivated pig serum, $0.1 \mathrm{mg}$ of gentamycin and 20 units of heparin $/ \mathrm{ml}$. The cells were plated at $5 \times 10^{6}-6 \times 10^{6}$ cells per $50 \mathrm{~mm}$ culture dish and incubated for $2 \mathrm{~h}$ at $37^{\circ} \mathrm{C}$ in an atmosphere of $\mathrm{CO}_{2}$ /air (1:19). The non-adherent cells were removed by washing the cell sheet with five $5 \mathrm{ml}$ volumes of normal saline $(0.9 \% \mathrm{NaCl})$. The remaining adherent cells have been shown to be greater than $95 \%$ macrophages as determined by morphological examination of Giemsa stained cultures.

Mouse LM fibroblasts were routinely maintained in serum-free Higuchi medium.

\section{Preparation of cell homogenates}

Adherent macrophages $\left(3 \times 10^{6}\right)$ were scraped into $1 \mathrm{ml}$ of normal saline using a rubber policeman, placed in a $15 \mathrm{ml}$ conical centrifuge tube and then pulse-sonicated for $30 \mathrm{~s}$ while suspended in an ice bath. Greater than $95 \%$ of the cells were disrupted by this procedure (Bonney et al., 1979b). The protein content of this preparation was determined by the method of Lowry et al. (1951). Cell sonicates were used immediately for assay of phospholipase C.

\section{Preparation of substrates}

Radiolabelled phosphatidylinositol substrates were prepared from mouse LM cells maintained in serum-free Higuchi medium devoid of choline, serine and inositol (Sundler et al., 1978). This medium contained $20 \mu \mathrm{Ci}$ of $\left[{ }^{3} \mathrm{H}\right] m y o$-inositol and, for dually-labelled substrates, $20 \mu \mathrm{Ci}$ of $\left[{ }^{14} \mathrm{C}\right]$ - arachidonic acid. Labelled LM cells were scraped from culture flasks in methanol/water $(5: 2, \mathrm{v} / \mathrm{v})$ and the lipids were extracted by the method of Bligh \& Dyer (1959). Radiolabelled phosphatidylinositol was separated to greater than $95 \%$ purity on silica-gel GF t.l.c. plates developed in chloroform/methanol/ acetic acid/water (25:15:2:1, by vol.). The specific radioactivity of the substrate, averaging $(2-4) \times 10^{4}$ d.p.m./nmol, was determined by relating lipid phosphorus content to ${ }^{3} \mathrm{H}$ and ${ }^{14} \mathrm{C}$ radioactivity (d.p.m.). Phosphorus determinations were performed using a modification of the method of Kraml (1966). Substrates were stored in chloroform at $0^{\circ} \mathrm{C}$ under $\mathrm{N}_{2}$ and were stable for greater than 60 days.

\section{Phospholipase C assay}

Enzyme activities were assayed in $80 \mu \mathrm{l}$ of $0.1 \mathrm{M}$-Tris/maleate buffer, $\mathrm{pH} 6.5$, with $1 \mathrm{~mm}-\mathrm{Ca}^{2+}$. This final mixture included $1-2 \mu \mathrm{g}$ of sonicatedmacrophage protein and radiolabelled $100 \mu \mathrm{M}$-phosphatidylinositol added as a liposomal suspension prepared by brief sonication in water. The reactions were performed at $37^{\circ} \mathrm{C}$ and were terminated after $30 \mathrm{~min}$ by the addition of $3.75 \mathrm{vol}$. of methanol/ chloroform $(2: 1, \mathrm{v} / \mathrm{v})$. The reactions were extracted by the method of Bligh \& Dyer (1959) and released $\left[{ }^{3} \mathrm{H}\right]$ phosphoinositol was quantified by determining the amount of radioactivity recovered in the aqueous phase. The aqueous product was identified by its co-migration with inositol 1-phosphate on silica-G t.l.c. plates developed in chloroform/ methanol/water $(6: 4: 1$, by vol.). This system gave $R_{F}$ values of 0.05 and 0.20 for inositol 1-phosphate and free inositol respectively. $\left[{ }^{14} \mathrm{C}\right]$ Diacylglycerol was quantified by spotting a portion of the organic phase on silica-gel $G$ t.l.c. plates and developing them in light petroleum (b.p. $35-60^{\circ} \mathrm{C}$ )/diethyl ether/acetic acid $(70: 30: 1$, by vol.). Diacylglycerol was detected visually by exposing the plates to $I_{2}$ vapour, identified by its co-migration with an authentic standard and quantified by determining the amount of radioactivity associated with the resulting spots. When drugs were included in the assay, all were dissolved in dimethyl sulphoxide. The final dimethyl sulphoxide concentration in the assay was $1 \%$ and it was included in the buffer blank and the 'no-drug' controls. The substrate concentration utilized in the phenothiazine experiments was $60 \mu \mathrm{M}$, the substrate concentration at half-maximum reaction velocity.

All assays were conducted under those conditions wherein the products of phospholipase $\mathrm{C}$ activity accumulated in a linearly increasing manner with respect to time of incubation and amount of protein assayed. The assay is linear beyond $1 \mathrm{~h}$ of reaction time and with greater than $7 \mu \mathrm{g}$ of protein in the reaction mixture. 


\section{Results and discussion}

To determine if a phospholipase $\mathrm{C}$ activity could be detected in the macrophage and to characterize this activity in terms of its $\mathrm{Ca}^{2+}$ requirement, substrate specificity and $\mathrm{pH}$ optimum, the following experiment was performed. Sonicated macrophages were incubated with $100 \mu \mathrm{M}-\left[{ }^{14} \mathrm{C}\right]$ arachidonoyl phosphatidyl $\left[{ }^{3} \mathrm{H}\right]$ inositol in reaction mixtures containing $1 \mathrm{mM}-\mathrm{Ca}^{2+}$ (its optimal concentration) or $1 \mathrm{mM}$-EDTA and buffers of increasing $\mathrm{pH}$. The data depicted in Fig. 1 show that phosphatidylinositol is hydrolysed to phosphoinositol and diacylglycerol at a neutral $\mathrm{pH}$ and is inhibited by EDTA. The equimolar recovery of phospho $\left[{ }^{3} \mathrm{H}\right]$ inositol and $\left[{ }^{14} \mathrm{C}\right]$ diacylglycerol throughout the active range of the enzyme establishes this as a phospholipase C activity. When this experiment was performed using dually-labelled phosphatidylcholine or duallylabelled phosphatidylethanolamine as substrates, no products of phospholipase $\mathrm{C}$ activity were detected. These results indicate that the macrophage enzyme is specific for phosphatidylinositol. The neutral $\mathrm{pH}$ optimum, $\mathrm{Ca}^{2+}$ requirement and phosphatidylinositol specificity show that this enzyme resembles the soluble phospholipase $\mathrm{C}$ activities reported in the platelet (Mauco et al., 1979; Rittenhouse-Simmons,

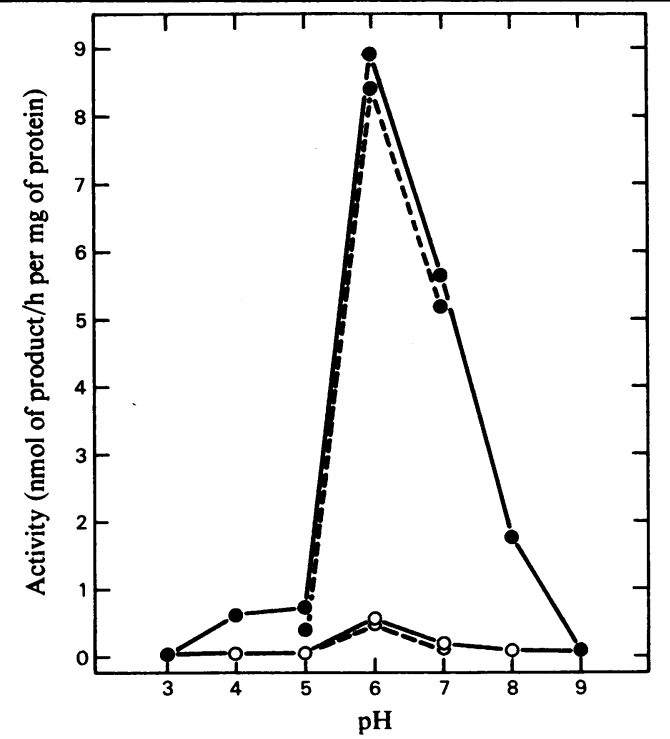

Fig. 1. Macrophage phospholipase $C$ activity as a function of $p H$

Reactions were performed in acetate buffer (pH 3-5), Tris/maleate buffer $(\mathrm{pH}$ 6-7) or Tris/HCl buffer (pH 8-9) containing $1 \mathrm{~mm}-\mathrm{Ca}^{2+}(0)$ or $1 \mathrm{~mm}$ EDTA (O). $\left[{ }^{14} \mathrm{C}\right]$ Arachidonoyl phosphatidyl $\left[{ }^{3} \mathrm{H}\right]$ inositol was used as substrate. Results are reported as $\mathrm{nmol}$ of phosphoinositol (-) or $\mathrm{nmol}$ of diacylglycerol (- - ) recovered/h per $\mathrm{mg}$ of protein. Each data point represents the mean of triplicate determinations with less than $10 \%$ deviation among determinations.
1979). It is noteworthy that under these conditions there is neither diacylglycerol lipase nor diacylglycerol kinase activity sufficient to deplete the diacylglycerol produced. Subsequent efforts to identify a diacylglycerol lipase optimally active at $\mathrm{pH} 7$ in the macrophage similar to that reported by Bell et al. (1979) in the platelet have not been successful. We have characterized another activity, however, which is very different from the platelet enzyme. This activity is independent of $\mathrm{Ca}^{2+}$ concentration, is optimal at $\mathrm{pH} 4.5$, is not augmented by reduced glutathione and has a maximum reaction velocity of $3 \mathrm{nmol} / \mathrm{h}$ per $\mathrm{mg}$ of protein.

Sonicated macrophages were assayed for phospholipase $\mathrm{C}$ activity with increasing amounts of phosphatidyl $\left[{ }^{3} \mathrm{H}\right]$ inositol as described in the Methods section. In this experiment phospholipase $\mathrm{C}$ activity reached a maximum reaction velocity of $525 \mathrm{nmol}$ of phosphatidylinositol hydrolysed/h per $\mathrm{mg}$ of protein and is fully saturated at a substrate concentration of $100 \mu \mathrm{M}$.

Mouse peritoneal macrophages, when exposed to an inflammatory stimulus such as zymosan or antigen-antibody complexes, release about $1-2 \mathrm{nmol}$ of prostaglandins $/ \mathrm{h}$ per $\mathrm{mg}$ of cell protein (Bonney et al., 1978a, 1979a). Prelabelled platelets exposed to stimulators such as thrombin and ionophore A23187 release about $20-30 \%$ of the incorporated radioactive arachidonic acid (Rittenhouse-Simmons et al., 1976). Vanderhoek \& Feinstein (1979) have reported that chlorpromazine, a phenothiazine, inhibits this stimulated release of oxygenated products of arachidonic acid from platelets. Chlorpromazine shows an $I_{50}$ of this release at a concentration of $50 \mu \mathrm{M}$. Accordingly, we have studied the effects of several phenothiazines on macrophage phospholipase $\mathrm{C}$ (Table 1). Although metiazinic acid shows an $I_{50}$ of $300 \mu \mathrm{M}$, the $I_{30}$ values for each of the other phenothiazines tested against the macrophage phospholipase $\mathrm{C}$ are well within the range of activity reported by Vanderhoek \& Feinstein (1979) for chlorpromazine inhibition of prostaglandin release. Conceivably, this compound could be exerting this inhibition at the level of the phospholipase C. Promethazine was also titrated against the $\mathrm{Ca}^{2+}$-dependent macrophage phospholipase $A_{2}$ activity that we have characterized (Wightman et al., 1981). It failed to show significant inhibition of this activity even at $1 \mathrm{~mm}$ concentration.

Other investigators have examined the effects of cationic drugs on phospholipase $\mathrm{C}$ hydrolysis of phosphotidylinositol. These reports demonstrate that chlorpromazine inhibits both the soluble lymphocyte phospholipase C (Allan \& Michell, 1974) and the lysosomal phospholipases $\mathrm{C}$ of rat liver and brain (Irvine et -al., 1978). Lullmann et al. (1980) have reported that this class of drug can displace 
Table 1. Inhibition of macrophage phospholipase $C$ activity by several phenothiazines

The compounds indicated below were included in the assay mixture described in the Methods section in dimethyl sulphoxide. The concentrations tested were $1 \mathrm{mM}, 0.1 \mathrm{mM}, 10 \mu \mathrm{M}$ and $1 \mu \mathrm{M}$. The final dimethyl sulphoxide concentration was $1 \% . I_{50}$ is the concentration at which the compound inhibits the phospholipase $\mathrm{C}$ by $50 \%$. These were calculated from the regression lines $y=a+b x$ relating phenothiazine concentration $(x)$ to percentage inhibition $(y)$. These data are representative of two independent experiments. The correlation coefficient for each regression line was greater than 0.950 . The percentage inhibition values were means of three determinations with the coefficients of variation less than $10 \%$ of the mean. These data are a representation of two independent experiments.

\begin{tabular}{lc}
\multicolumn{1}{c}{ Compound } & $\mathrm{I}_{50}(\mu \mathrm{M})$ \\
Methdilazine & 3.2 \\
Promethazine & 5.0 \\
Chlorpromazine & 6.3 \\
Prochlorperazine & 20.0 \\
Trimeprazine tartrate & 25.0 \\
Dimethothiazine mesylate & 45.0 \\
Metiazinic acid & 300.0
\end{tabular}

bound $\mathrm{Ca}^{2+}$ from phosphatidylinositol monolayers with an $\mathrm{I}_{50}$ of about $50 \mu \mathrm{M}$. To address the question as to whether this was the mechanism of phenothiazine inhibition of macrophage phospholipase C, promethazine was titrated from $1 \mu \mathrm{M}$ to $1 \mathrm{mM}$ against the phospholipase $\mathrm{C}$ activity in the absence of exogenous $\mathrm{Ca}^{2+}$ or increasing amounts of $\mathrm{Ca}^{2+}$ added in $2 \mathrm{mM}$ increments up to $10 \mathrm{mM}$. The mean ( \pm S.D.) of the $\mathrm{I}_{50}$ values at each $\mathrm{Ca}^{2+}$ concentration was $5.2 \pm 0.01 \mu \mathrm{M}$. Hence the inhibition of macrophage phospholipase $\mathrm{C}$ is independent of the $\mathrm{Ca}^{2+}$ concentration employed. The mechanism of inhibition of macrophage phospholipase $\mathrm{C}$ by phenothiazines remains to be resolved. However, it is likely that the active moiety of the phenothiazines may be the ionizable amine. Certain compounds similar in structure to the phenothiazines and bearing an ionizable amine also inhibit macrophage phospholipase $\mathrm{C}$ at similar concentrations. These compounds include chloroquine, mepacrine and cyproheptadine tartrate (P. D. Wightman, unpublished work).

In conclusion we have characterized a phospholipase $\mathrm{C}$ activity in mouse macrophages that may be of importance in the response of the macrophage to inflammatory stimuli. Furthermore we have shown that this activity can be inhibited by phenothiazines, compounds that have been shown to inhibit the release of prostaglandins from stimulated platelets and arachidonic acid from stimulated macrophages.

\section{References}

Allan, D. \& Michell, R. H. (1974) Biochem. J. 142, 591-597

Apitz-Castro, R. J., Mas, M. A., Cruz, M. R. \& Toin, M. K. (1979) Biochem. Biophys. Res. Commun. 91, 63-71

Bell, R. L., Kennerly, D. A., Stanford, N. \& Majerus, P. W. (1979) Proc. Natl. Acad. Sci. U.S.A. 76, 3238-3241

Bligh, E. G. \& Dyer, W. J. (1959) Can. J. Biochem. Physiol. 37, 911-917

Bonney, R. J., Wightman, P. D., Davies, P., Sadowski, S. J., Kuehl, F. A., Jr. \& Humes, J. L. (1978a) Biochem.J. 176, 433-442

Bonney, R. J., Naruns, P., Davies, P. \& Humes, J. L. (1979a) Prostaglandins 18, 605-616

Bonney, R. J., Wightman, P. D. \& Davies, P. (1979b) Biochem. Pharmacol. 28, 2471-2478

Bonney, R. J., Wightman, P. D., Dahlgren, M. E., Davies, P., Kuehl, F. A., Jr. \& Humes, J. L. (1980) Biochim. Biophys. Acta 633, 410-421

Graham, R. C., Karnovsky, M. J., Shofer, A. W., Glass, E. A. \& Karnovsky, M. L. (1967) J. Cell. Biol. 32, 629-647

Hsueh, W., Kuhn, C. \& Neddleman, P. (1979) Biochem. J. 184, 345-354

Humes, J. L., Ham, E. A., Egan, R. W., Bonney, R. J., Davies, P. \& Kuehl, F. A., Jr. (1979) Agents Actions Suppl. 4, 96-105

Irvine, R. F., Hemington, N. \& Dawson, R. M. C. (1978) Biochem. J. 176, 475-484

Karnovsky, M. L., Shofer, A. W., Cagan, R. H., Graham, R. C., Karnovsky, M. J., Glass, E. A. \& Saito, K. (1966) Trans. N.Y. Acad. Sci 28, 778-787

Kraml, M. (1966) Clin. Chim. Acta. 13, 442-448

Lapetina, E. G. \& Cuatrecasas, P. (1979) Biochim. Biophys. Acta 573, 394-402

Lowry, O. H., Rosebrough, N. J., Farr, A. L. \& Randall, R. J. (1951) J. Biol. Chem. 193, 265-275

Lullmann, H., Plosch, H. \& Ziegler, A. (1980) Biochem. Pharmacol. 29, 2969-2974

Mauco, G., Chap, H. \& Douste-Blazy, L. (1979) FEBS Lett. 100, 367-370

Ogmundsdötter, H. M. \& Weir, D. M. (1979) Immunology 37, 689-696

Rittenhouse-Simmons, S. (1979) J. Clin. Invest. 63, 580-587

Rittenhouse-Simmons, S., Russell, F. A. \& Deykin, D. (1976) Biochem. Biophys. Res. Commun. 70, 295-301

Schroeder, F., Perlmutter, J. F., Glaster, M. \& Vagelos, P. R. (1976) J. Biol. Chem. 251, 5015-5026

Scott, W. A., Zrike, J. M., Hamill, A. L., Kempe, J. \& Cohn, Z. (1980) J. Exp. Med. 152, 324-335

Sundler, R., Alberts, A. W. \& Vagelos, P. R. (1978) J. Biol. Chem. 253, 4175-4178

Tyson, C. A., Zande, H. V. \& Green, D. E. (1976) J. Biol. Chem. 251, 1326-1332

Vanderhoek, J. Y. \& Feinstein, M. B. (1979) Mol. Pharmacol. 16, 171-180

Wightman, P. D., Davies, P. \& Bonney, R. J. (1981) Biochem. J. 195, 427-433 